\title{
Spondylocostal Dysostosis Associated with Type I Split Cord Malformation and Double Nipple on One Side: A Case Report
}

\author{
Tip 1 Split Kord Malformasyonu ve Bir Tarafta Çift Meme Başının Eşlik \\ Ettiği Spondilokostal Dizostozis: Bir Olgu Sunumu
}

Muhammet Bahadır YILMAZ 1 , Aysegul KAYMAK ${ }^{2}$, Gokhan KURT', Ferda Emriye PERCIN', Kemali BAYKANER ${ }^{1}$
${ }^{1}$ Gazi University, Faculty of Medicine, Division of Pediatric Neurosurgery, Department of Neurosurgery, Ankara, Turkey
${ }^{2}$ Gazi University, Faculty of Medicine, Department of Medical Genetics, Ankara, Turkey
Presented in: This paper was presented in the XXI. Congress of Turkish Neurosurgical Society Antalya 2007.

Correspondence address: Muhammet Bahadır YILMAZ / E-mail: bahadiryilmaz@yahoo.com.tr

\begin{abstract}
Jarcho Levin syndrome is a rare genetic disorder characterized by multipl vertebral and costal anomalies at birth. Jarcho Levin syndrome includes two phenotypic groups: spondylothoracic dysostosis and spondylocostal dysostosis. The prognosis of spondylothoracic dysostosis has worse than spondylocostal dysostosis, because of respiratory complications. Associated malformations include those of the congenital heart disease, urogenital malformation, skeletal anomalies and neural tube defects. We present a patient with spondylocostal dysostosis, who also had type I split cord malformation, tethered cord, scoliosis and double nipple on the right. Although the association of spondylocostal dysostosis and type I split cord malformation is very rare, double nipples on one side is no previously reported.
\end{abstract}

KEYWORDS: Spondylocostal dysostosis, Spondylothoracic dysostosis, Jarcho Levin syndrome, Congenital scoliosis, Accessory nipple, Type I split cord malformation

öz

Jarcho Levin Sendromu doğumda multipl vertebral ve kostal anomalileri ile karakterize,nadir bir genetik hastalıktır. Jarcho Levin Sendromu iki fenotipik grup içerir: spondilotorasik dizostozis ve spondilokostal dizostozis. Solunumsal komplikasyonlar nedeniyle spondilotorasik dizostozisin prognozu spondilokostal dizostozisden daha kötüdür. Konjenital kalp hastalıkları, ürogenital malformasyonlar, iskelet anomalileri ve nöral tüp defektleri eşlik eden anomalilerdir. Biz aynı zamanda tip 1 split kord malformasyon, gergin kord, skolyoz ve sağ tarafta çift meme başına sahip olan spondilokostal dizostozisli hasta sunuyoruz. Spondilokostal dizostozis ve tip 1 split kord birlikteliği çok nadir olmakla birlikte, bir tarafta çift meme başının eşlik etmesi daha önce rapor edilmemiştir.

ANAHTAR SÖZCÜKLER: Spondilokostal dizostozis, Spondilotorasik dizostozis, Jarcho Levin sendromu, Konjenital skolyoz, Aksesuar meme başı, Tip 1 split kord malformasyonu

\section{INTRODUCTION}

Jarcho Levin syndrome (JLS) is a rare genetic disorder characterized by multiple vertebral and costal anomalies at birth. This syndrome is usually diagnosed in newborns. Jarcho and Levin first described cases in 1938 (8). Solomon et al. classified cases of JLS into two phenotypic groups: spondylothoracic dysostosis (STD) and spondylocostal dysostosis (SCD) $(4,15)$. The prognosis of STD is grimmer than SCD, because of restrictive lung disease, pulmonary hypertension, congestive heart failure and respiratory infections $(4,10,14,17)$. In addition, congenital heart defects, abdominal wall malformations, urogenital and anal abnormalities, multiple skeletal anomalies, upper limb anomalies, spina bifida, inguinal, umblical and diaphragmatic hernias have been described in $\operatorname{JLS}(5,6,12$, $13,17)$.
We present a patient with $S C D$, who also had type I split cord malformation, tethered cord, scoliosis and double nipple on the right without respiratory problems. Although the association of SCD and type I split cord malformation is very rare, double nipples on one side is not previously reported.

\section{CASE REPORT}

A 2-year-old female child presented with thoracolumbar scoliosis, and skin lesion, hypertrichosis and red discolouration at thoracolumbar junction (Figure 1). We found double nipples on the right side during physical examination of the patient (Figure 1). Skin lesion on the back of the patient showed similarity of radiological image of split cord (Figure 1). The neurological examination was normal. There was no respiratory problem. Our patient's chromosomal analysis was 
normal. Radiological examination showed that the conus was tethered, type I split cord malformation consists of two hemicords at the level of L2 vertebra, and multiple vertebral deformities at the level of T9 between L1 (Figure 2). The first four ribs were absent on right side. There was an irregular appearance at the fifth with sixth ribs, and seventh with eighth ribs (Figure 2). In addition, X-ray demonstrated that the median dense area at the level of L2 (Figure 2). Her parents had no vertebral anomaly. She was operated and the bone septum was removed (Figure 3). Two hemicords within two separate dural sheaths were placed into same dura. There was no neurological deficit after the operation. She was followed in terms of tethered cord and respiratory complications.

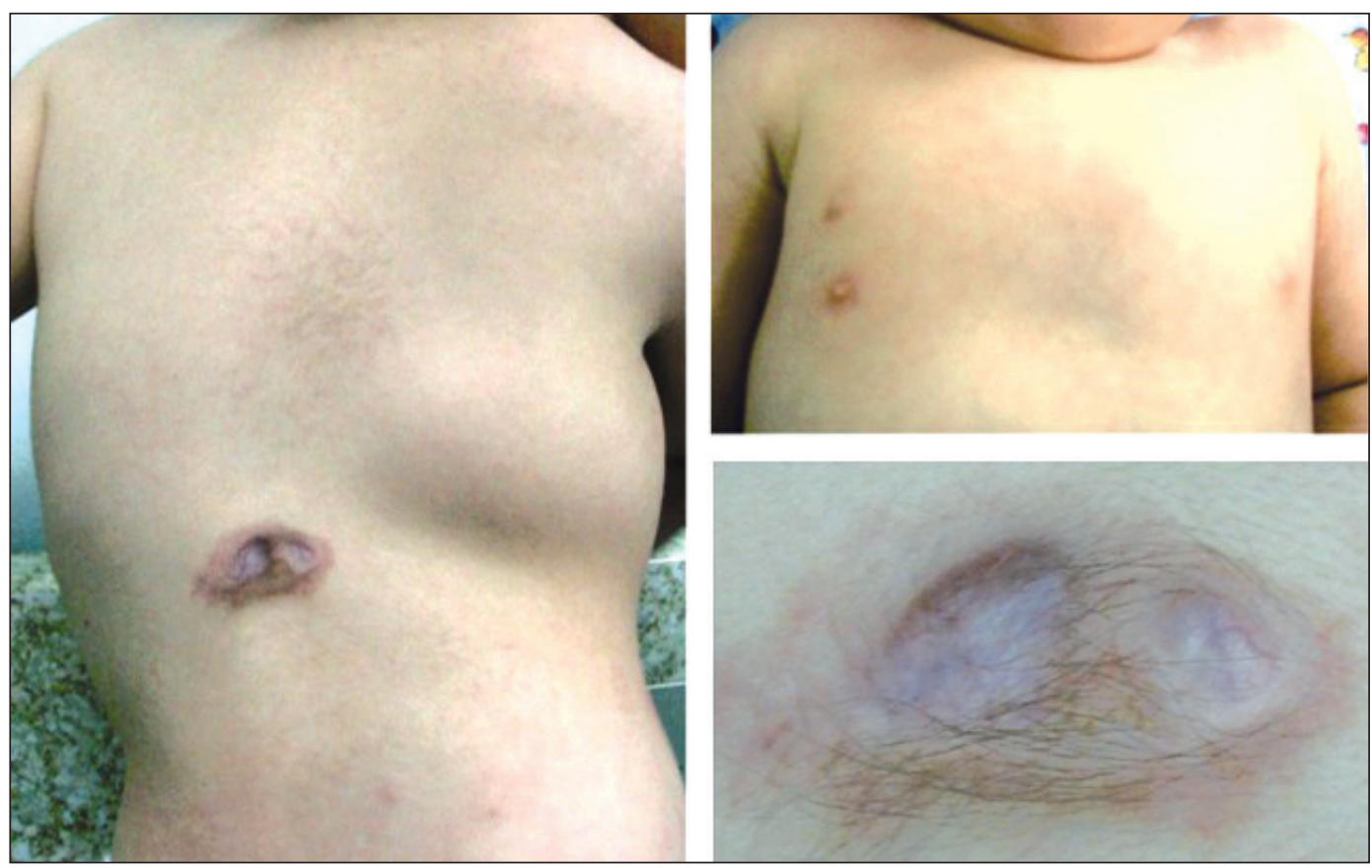

Figure 1: Picture showing a scoliosis, hypertrichosis, red discolouration at thoracolumbar junction, and double nipples on the right side. Skin lesion on the back of the patient showing similarity of radiological image of split cord.
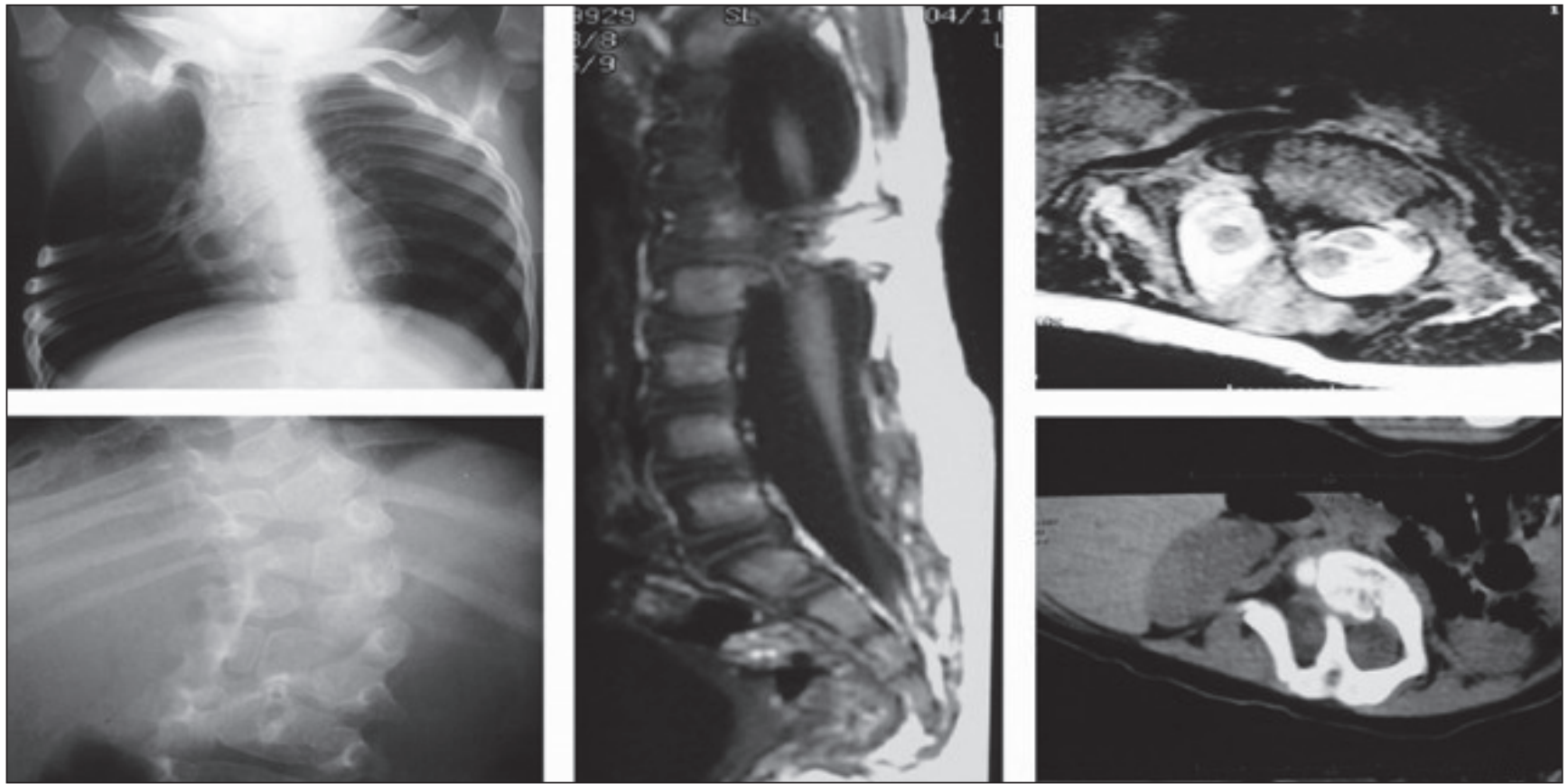

Figure 2: Chest radiograph shows the right first four ribs to be missing, irregular fusion of the ribs (5-8) on the right side. In addition, spine radiograph shows the median dense area at the level of L2, and multiple vertebral deformities at the level of T9 between L1. Magnetic resonance images show tethered cord, type I split cord malformation consists of two hemicords at the level of $L 2$ vertebrae. Computed tomography shows bone septum at the level of $L 2$ vertebrae. 

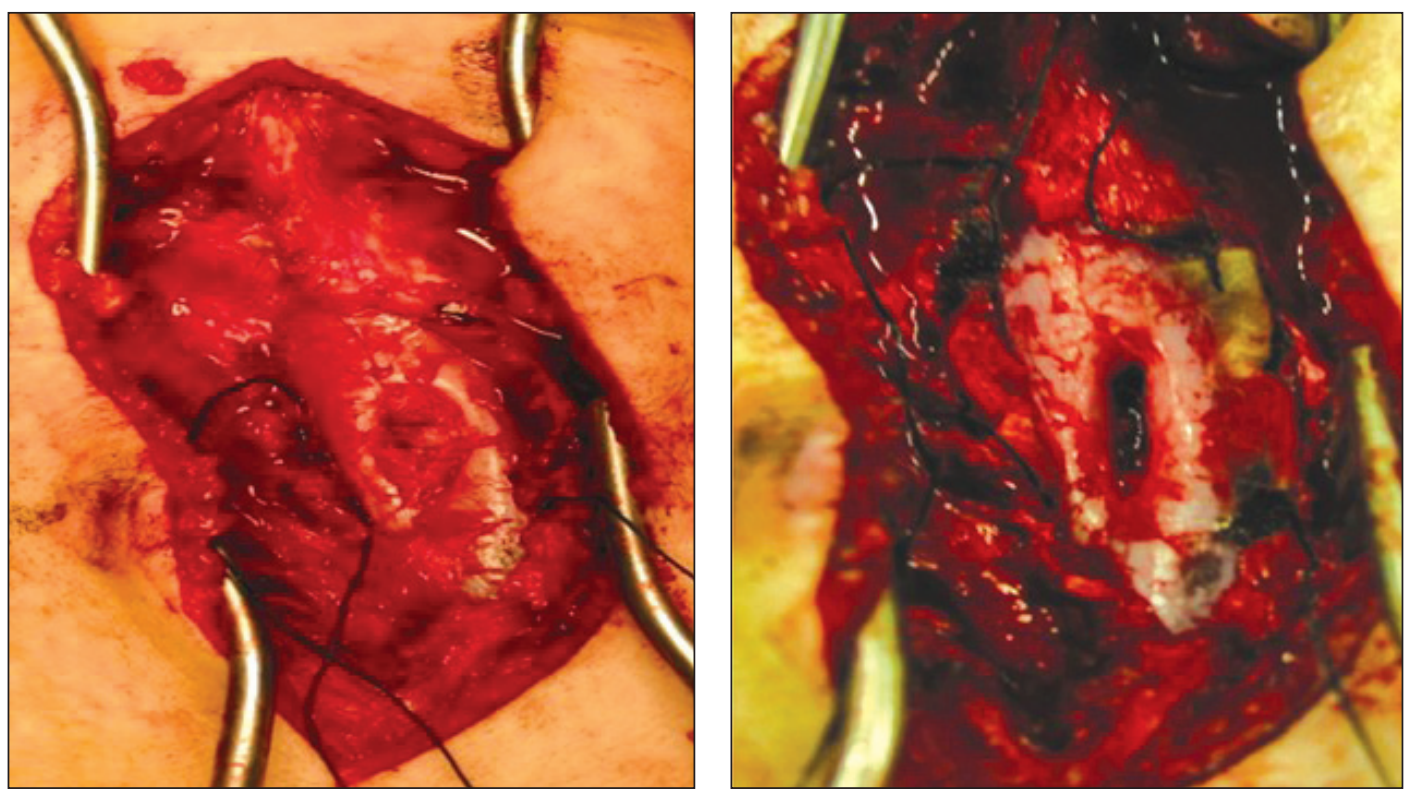

Figure 3: Picture showing bone septum and postoperative appearance.

\section{DISCUSSION}

Jarcho and Levin first described cases in 1938 (8). They described two sibs with short neck and short thorax resulting from multiple congenital vertebral and rib cage malformations $(2,17)$. In 1978, Solomon et al. classified cases of JLS into two phenotypic groups: spondylothoracic dysostosis (STD) and spondylocostal dysostosis (SCD) $(4,15)$. The incidence is unknown for STD, but SCD has a reported prevalence of 0.2 per 100,000 liveborns $(2,11,17)$. Although Campbell reported no gender predilection, Vázquez-López reported that it is more common in females $(2,17)$.

SCD is also a rare congenital disorder with multiple vertebral and numerical or structural rib abnormalities that resulting in thoracic asymmetry and short stature and neck (7). Rib anomalies include absence, posterior fusion and irregular or bifid ribs $(4,17)$. STD is a rare congenital disorder with segmentation and formation defects in cervical, thoracic and lumbar spine such as hemivertebrae, block vertebrae, butterfly vertebrae, and unsegmented bars with fusion of all the ribs at the costovertebral junction (10). Hemivertabrae is the most common spinal anomaly and seen mostly in the thorocolumbar region $(4,9)$ STD is a characterized by the presence of 'crab-like' chest, but there are no intrinsic rib malformations reported $(4,14)$.

The prognosis of STD is grimmer than SCD, because of restrictive lung disease, pulmonary hypertension, congestive heart failure and respiratory infections $(4,14,17)$. Dane et al. reported $45 \%$ mortality in neonatal or infancy with STD from restrictive lung disease, pulmonary hypertension, congestive heart failure and respiratory infections $(2,4,5,10,14,17)$. Patient with SCD has usually a much lower mortality rate. Most cases of SCD are transmitted in autosomal recessive way, but rarely autosomal dominant transmission was reported $(7,9$,
$13,17)$. STD has autosomal recessive transmission way $(9,17)$. Patients with SCD have mutations in the delta-like 3 (DLL3) gene on chromosome $19(1,7,10,16,17)$. Children with STD have no mutations in the DLL3 gene $(3,17)$. Whittock et al. demonstrated a mutation in the MESP 2 gene in 2 sibs affected by a mild variety of $\operatorname{SCD}(10,18)$.

Scoliosis occurs in one-third of the JLS (17). Other associated anomalies include congenital heart defects, abdominal wall malformations, inguinal, umbilical and diaphragmatic hernias, urinary tract and renal malformations, anal atresia, upper limb anomalies, spina bifida $(5,6,12,13,17)$. Less commonly, other skeletal malformations such as winged scapula, irregular clavicle, absent atlas, and hypoplastic humerus can be found. Most patients do not have craniofacial malformations $(9,17)$.

Although the association of SCD and type I split cord malformation is described, the association between those pathologies and double nipples on one side is not previously reported.

Although prenatal ultrasound diagnosis can be practiced as early as 16 . weeks of gestation (10), in some cases could be difficult. Ultrasound characteristically revealed presence of fanned out ribs and skeletal defects.

The aim of management, should be suitable patient care, prevention and early, aggressive treatment of respiratory infections. Preoperative pulmonary function tests are important. The lung capacity of the child younger than age 6 years should be assessed with tomography (2).

Spinal surgery of those cases prevents scoliosis and pulmonary restriction. Hence associated pulmonary and cardiac complications could be decreased (10). Reconstructive surgery to gain more thoracic volume by titanium rib implants has been described in the treatment of that disorder. 


\section{ACKNOWLEDGEMENT}

This paper was presented in the XXI. Congress of Turkish Neurosurgical Society Antalya 2007.

\section{REFERENCES}

1. Bulman MP, Kusumi K, Frayling TM, McKeown C, Garrett C, Lander ES, Krumlauf R, Hattersley AT, Ellard S, Turnpenny PD: Mutations in the human delta homologue, DLL3, cause axial skeletal defects in spondylocostal dysostosis. Nature Genet 24: 438-441, 2000

2. Campbell RM Jr: Spine deformities in rare congenital syndromes: Clinical issues. Spine (Phila Pa 1976) 34(17): 1815-1827, 2009

3. Cornier AS, Ramirez N, Carlo S, Reiss A: Controversies surrounding Jarcho-Levin syndrome. Curr Opin Pediatr 15:614-620, 2003

4. Cetinkaya M, Ozkan H, Koksal N, Yazici Z, Yalcinkaya U: Spondylocostal dysostosis associated with diaphragmatic hernia and neural tube defects. Clin Dysmorphol 17(2): 151-154, 2008

5. Dane B, Dane C, Aksoy F, Cetin A, Yayla M: Jarcho-Levin syndrome presenting as neural tube defect: Report of four cases and pitfalls of diagnosis. Fetal Diagn Ther 22(6): 416-419, 2007

6. Duru S, Ceylan S, Guvenc BH, Ceylan S: Segmental costovertebral malformations: Association with neural tube defects. Pediatr Neurosurg 30:272-277, 1999

7. Etus V, Ceylan S, Ceylan S: Association of spondylocostal dysostosis and type I split cord malformation. Neurol Sci 24(3):134-137, 2003

8. Jarcho S, Levin PM: Hereditary malformation of the vertebral bodies. Bull John Hopkins Hosp 62:216-226, 1938

9. Karnes PS, Day D, Berry SA, Pierpont ME: Jarcho-Levin syndrome: Four new cases and classification of subtypes. Am J Med Genet 40(3):264-270, 1991
10. Kulkarni ML, Navaz SR, Vani HN, Manjunath KS, Matani D: Jarcho-Levin syndrome. Indian J Pediatr 73(3):245-247, 2006

11. Martínez-Frías $M L$, Bermejo $E$, Paisán $L$, Martín $M$, Egüés J, López JA, Martínez S, Orbea C, Cucalón F, Gairi JM, et al: Severe spondylocostal dysostosis associated with other congenital anomalies: A clinical/epidemiologic analysis and description of ten cases from the Spanish registry. Am J Med Genet 51(3):203-212, 1994

12. McCall CP, Hudgins L, Cloutier M, Greenstein RM, Cassidy SB: Jarcho-Levin syndrome: Unusual survival in a classical case. Am J Med Genet 49:328-332, 1994

13. Nadkarni TD, Menon RK, Desai KI, Goel A: Segmental costovertebral malformation associated with lipomyelomeningocoele. J Clin Neurosci 12(5):599-601, 2005

14. Onay OS, Kinik ST, Otgun Y, Arda IS, Varan B: Jarcho-Levin syndrome presenting with diaphragmatic hernia. Eur J Pediatr Surg 18(4):272-274, 2008

15. Solomon L, Jimenez RB, Reiner L: Spondylothoracic dysostosis: Report of 2 cases and review of the literature. Arch Path Lab Med 102:201-205, 1978

16. Turnpenny PD, Bulman MP, Frayling TM, Abu-Nasra TK, Garrett C, Hattersley AT, Ellard S: A gene for autosomal recessive spondylocostal dysostosis maps to 19q13.1-q13.3. Am J Hum Genet 65:175-182,1999

17. Vázquez-López ME, López-Conde MI, Somoza-Rubio C, PérezPacín R, Morales-Redondo R, González-Gay MA: Anomalies of vertebrae and ribs: Jarcho Levin syndrome. Description of a case and literature review. Joint Bone Spine 72(3): 275-277, 2005

18. Whittock NV, Sparrow DB, Wouters MA, Sillence D, Ellard S, Dunwoodie SL, Turnpenny PD: Mutated MESP2 causes spondylocostal dysostosis in humans. Am J Hum Genet 74:1249-1254, 2004 